\title{
Temporal and geographic differences in feeding and nutritional condition of walleye pollock larvae Theragra chalcogramma in Shelikof Strait, Gulf of Alaska
}

\author{
Michael F. Canino ${ }^{1}$, Kevin M. Bailey ${ }^{1}$, Lewis S. Incze ${ }^{2}$ \\ ${ }^{1}$ Alaska Fisheries Science Center, National Oceanic and Atmospheric Administration, 7600 Sand Point Way NE, BIN C15700, \\ Seattle, Washington 98115-0700, USA \\ ${ }^{2}$ Bigelow Laboratory for Ocean Sciences, West Boothbay Harbor, Maine 04575, USA
}

\begin{abstract}
Feeding and nutritional condition of first-feeding walleye pollock larvae Theragra chalcogramma were compared to available prey levels measured during early spring (late April- early May) and mid-spring (mid-May) 1989. In early spring, feeding intensity, mean RNA/DNA values of larvae, and microzooplankton abundance were higher within a large patch of larvae compared with areas outside the patch. In mid-spring, microzooplankton prey abundance, feeding levels and RNA/DNA of larvae in and out of the previously defined patch were higher, indicating better overall conditions for growth than in early spring. The results suggest that limiting food densities may occur during spring over spatial and temporal scales that affect feeding and growth of larval pollock.
\end{abstract}

\section{INTRODUCTION}

Walleye pollock Theragra chalcogramma form dense spawning aggregations during late March to mid-April in Shelikof Strait, Gulf of Alaska. The resultant patches of eggs and developing larvae drift generally southwest along the continental shelf of the Alaska Peninsula (Kendall et al. 1987, Kendall \& Picquelle 1990). Larvae begin to feed about 5 to $6 \mathrm{~d}$ after hatching, primarily upon naupliar stages of copepods (Kamba 1977, Nishiyama \& Hirano 1983, 1985, Dagg et al. 1984, Kendall et al. 1987, Nakatani 1988). Maximum numbers of copepod nauplii occur in the upper $45 \mathrm{~m}$ (Incze et al. 1990) and are generally coincident with the depth of first-feeding pollock larvae (Kendall et al. 1987, Kim \& Kendall 1989).

The ratio of ribonucleic acid (RNA) to deoxyribonucleic acid (DNA) has been demonstrated to be a reliable and sensitive indicator of recent growth and general nutritional condition for larvae of several marine fish species (Buckley 1979, 1980, 1981, 1984, Buckley et al. 1984, Clemmensen 1987, Robinson \& Ware 1988). The DNA content per cell is relatively constant and has been useful as an indicator of cell number or biomass (see Bulow 1987 for review). RNA content, consisting mostly of ribosomal RNA, reflects precursory biochemical processes for protein synthesis and growth. The ratio of RNA/DNA reflects the recent metabolic history of a larva and is primarily determined by temperature and feeding conditions.

Detectable changes in RNA/DNA occur within a few days from the onset of starvation in the laboratory (Buckley et al. 1984, Wright \& Martin 1985, Clemmensen 1987, 1988, Robinson \& Ware 1988, Richard et al. 1991). Several studies have compared RNA/DNA of larvae starved in the laboratory with those captured in the field (Setzler-Hamilton et al. 1987, Robinson \& Ware 1988, Hovenkamp 1990). A positive relationship of RNA/DNA to prey abundance has been shown for striped bass larvae (Martin et al. 1985), and larvae of Atlantic cod and haddock (Buckley \& Lough 1987). Conversely, low RNA/DNA values may imply that prey densities are too low for optimal growth of fish larvae. Previous studies did not attempt to quantify nutritional condition, as evidenced by RNA/DNA ratios, as a function of ingestion by fish larvae. 
Our objective was to examine the relationships between microzooplankton abundance, feeding intensity of larvae, and the nutritional status of first-feeding walleye pollock. The detection of a dense patch of larvae during sampling provided spatial and temporal contrasts with areas outside the patch. The results indicate a linkage between food availability, feeding, and growth during an early period of larval development.

\section{METHODS}

Field collections. Ichthyoplankton samples were collected during 2 research cruises: Cruise 2MF89 (27 April to 2 May) and Cruise 3MF89 (9 to 16 May 1989) aboard the NOAA research vessel 'Miller Freeman' (Figs. 1 \& 2). A grid of stations spaced $10 \mathrm{n}$ miles apart, extending from northern Shelikof Strait to the Semidi Islands, was sampled during each cruise using a MARMAP double oblique tow (Posgay \& Marak 1980) with a $60 \mathrm{~cm}$ bongo sampler fitted with two $333 \mu \mathrm{m}$ mesh nets. Tows were taken to $100 \mathrm{~m}$ where depths permitted, and were profiled by a bathykymograph mounted to the net harness.

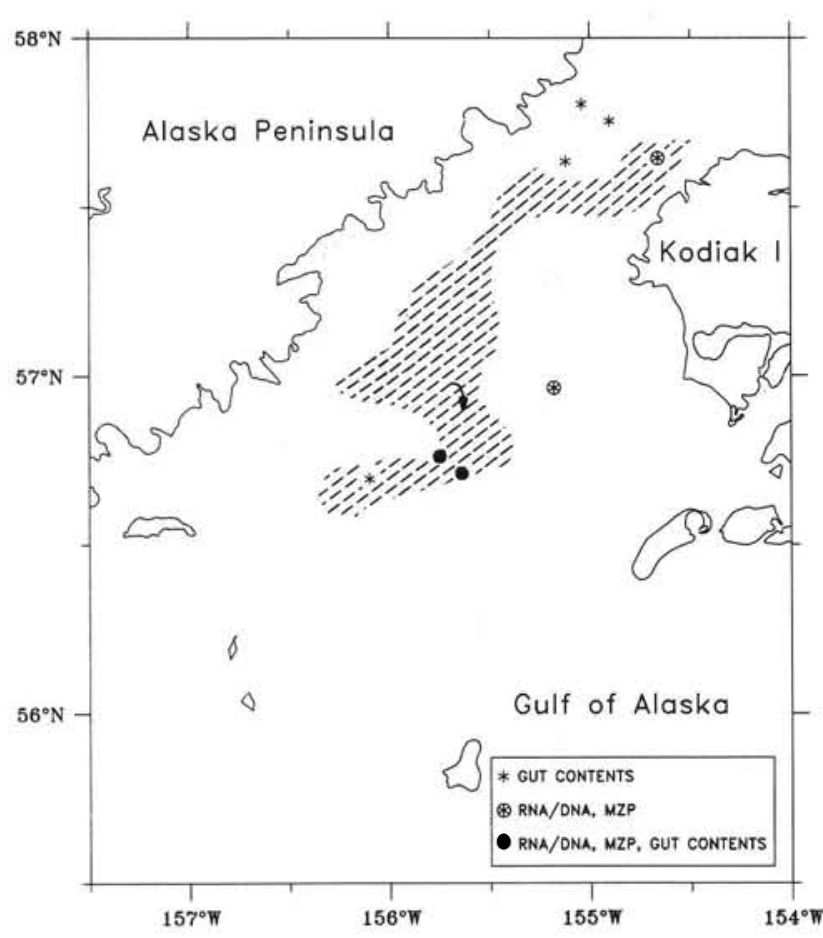

Fig. 1. Locations of sampling stations and key to sampling activities during Cruise 2MF89, 27 April to 2 May 1989. MZP: microzooplankton samples. Arrowed line: satellite-tracked drifter trajectory 3 to 5 May 1989. Shaded area: larval pollock densities exceeding 2000 larvae $10 \mathrm{~m}^{-2}$

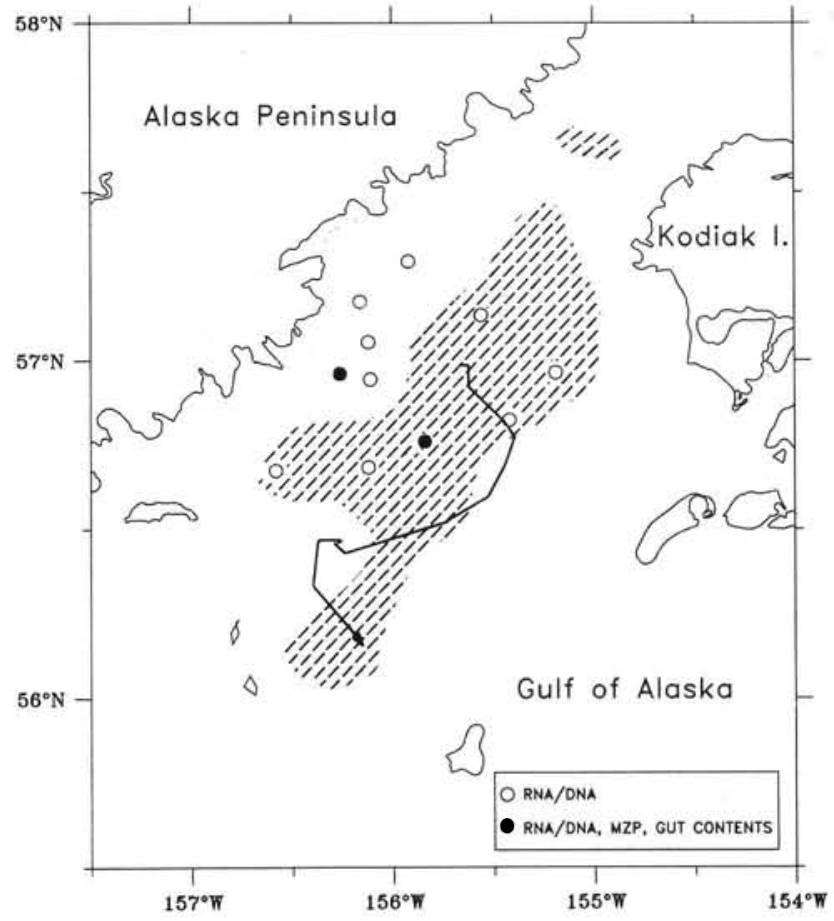

Fig. 2. Locations of sampling stations and key to sampling activities during Cruise 3MF89, 9 to 16 May 1989. MZP: microzooplankton samples. Arrowed line: satellite-tracked drifter trajectory from original deployment on 3 May until 14 May. Shaded areas designate larval pollock densities exceeding 1000 larvae $10 \mathrm{~m}^{-2}$

Pollock larvae from one of the bongo nets were counted aboard ship for approximations of larval abundance. Contents of the other net were preserved in $2 \%$ buffered formaldehyde ( $5 \%$ formalin) in seawater for later processing and gut content analyses. Shipboard counts of larvae from 88 stations during Cruise 2MF89 determined the presence of a large patch of larvae and eggs (ca $1600 \mathrm{~km}^{2}$ ) within the sampling grid (Fig. 1). Patch boundaries were designated where the number of larvae captured per tow fell below $200010 \mathrm{~m}^{-2}$. An ARGOS satellite-tracked drifter, drogued at $45 \mathrm{~m}$, was deployed near the center of the abundance of larvae during Cruise 2MF89. The drifter trajectory and location provided an approximate area for resampling the patch of larvae. Sampling procedures were similar during Cruise 3MF89, except that 117 stations were sampled and the patch was defined by stations having more than 1000 larvae $10 \mathrm{~m}^{-2}$, which allowed for a decline in numbers of $50 \%$ between the 2 sampling periods, occurring at a rate of about $6 \% \mathrm{~d}^{-1}$.

Microzooplankton were sampled from 0 to $60 \mathrm{~m}$ in $10 \mathrm{~m}$ increments with 101 Niskin bottles deployed in a rosette sampler coupled with a Seabird continuous temperature and depth (CTD) monitoring system. Four 
stations ( 2 in patch/2 out of patch) were sampled once during Cruise 2MF89. Two stations (1 in patch/1 out of patch) were each occupied 3 times for diel sampling during Cruise 3MF89 (Fig. 2). Samples were concentrated on $40 \mu \mathrm{m}$ mesh Nitex sieves, and then rinsed into storage jars containing $2 \%$ buffered formaldehyde in seawater.

Larvae for RNA/DNA samples were collected by a 60 $\mathrm{cm}$ bongo net with brief vertical tows from 0 to $60 \mathrm{~m}$ at stations inside or outside of the patch. Live pollock larvae between 5.0 and $7.0 \mathrm{~mm}$ were immediately removed and sorted over ice to prevent autolytic loss of nucleic acids. Larvae were quickly measured to the nearest $0.1 \mathrm{~mm}$ with an ocular micrometer, then placed in $1.5 \mathrm{ml}$ polyethylene centrifuge tubes and frozen at $-80^{\circ} \mathrm{C}$. Total time from collection to freezing did not exceed $10 \mathrm{~min}$.

Laboratory procedures. Standard lengths (SL) of preserved pollock larvae between 5.0 and $7.0 \mathrm{~mm}$ were measured to the nearest $0.1 \mathrm{~mm}$ using a dissecting microscope with an ocular micrometer. The entire digestive tract from each larva was dissected under high magnification and gut contents briefly stained with a $200 \mu \mathrm{g} \mathrm{ml}^{-1}$ solution of Alcian Blue to enhance contrast. Prey items in the gut were assigned to 6 prey categories: copepod nauplii, copepod eggs, euphausiid nauplii, unidentified crustaceans, unidentified eggs, and unidentified other. Prosome lengths were measured to the nearest $5.0 \mu \mathrm{m}$ on all intact nauplii.

Food rations ingested by pollock larvae in and out of the patch locations were estimated from gut contents. We assumed that ingestion and gut evacuation rates were constant for the types and amount of food consumed during the daily feeding period. Daily food consumption $(D)$ was estimated by a modified version of Bajkov's (1935) equation:

$$
D=A \frac{16}{n}
$$

where $A=$ mean amount of food during the feeding period; and $n=$ gut passage time in hours. We assumed that a $16 \mathrm{~h}$ feeding period given by Dagg et al. (1984) for pollock larvae in the southeastern Bering Sea during May was similar for larvae in Shelikof Strait. Therefore, ration estimates were derived only from larvae collected between 06:00 and 22:00 h. The digestion time was assumed to be $5.0 \mathrm{~h}$. Observations of gut passage time by first-feeding pollock larvae ingesting Acartia spp. nauplii at $6{ }^{\circ} \mathrm{C}$ (Canino \& Bailey unpubl.) support the $5.0 \mathrm{~h}$ digestion time reported by Paul (1983) for larvae to clear their guts of copepod nauplii while continuing to feed on rotifers at $5.5^{\circ} \mathrm{C}$.

Weight-specific rations, as fractions of body dry weight or carbon ingested per day, were estimated for first-feeding larvae from inside and outside of the patch stations. Carapace lengths of nauplii from gut contents from each cruise and location were assigned to 12 prey size categories ranging from 100 to $400 \mu \mathrm{m}$ in $25 \mu \mathrm{m}$ increments. Prey size distributions in the guts were not significantly different between cruises or locations (Kolmogorov-Smirnov test, $\mathrm{p}>0.1$ ). Copepod nauplii were assumed to be Pseudocalanus spp., because adults of this species dominate the copepod assemblage in Shelikof Strait during early May (Siefert \& Incze 1991). Mean carbon weight for each prey category was apportioned based on values for naupliar N1-N6 stages of Pseudocalanus given by Davis (1984) and Landry \& Lorenzen (1989). The frequency of prey in each size class was multiplied by a mean dry weight or carbon weight for that class and then summed to provide an average total prey weight in terms of dry weight or carbon. The dry weight of a $5.5 \mathrm{~mm}$ pollock larva $(143.6 \mu \mathrm{g})$ was predicted from the regression equation given by Yamashita \& Bailey (1990) for fieldcollected larvae; carbon weight of larvae was estimated to be $44.5 \%$ of dry weight (Harris 1985).

A sequential enzymatic digestion procedure modified from Bentle et al. (1981) was used to determine nucleic acid contents. Individual pollock larvae were homogenized in pre-chilled glass homogenizers in 300 or $400 \mu \mathrm{l}$ of $1 \mathrm{M} \mathrm{NaCl}$ depending on size. Two replicate $100 \mu \mathrm{l}$ aliquots were combined with $1 \mathrm{ml}$ of $5 \mu \mathrm{g} \mathrm{ml}^{-1}$ ethidium bromide solution, $400 \mu \mathrm{l}$ of deionized, distilled water, and $15 \mu \mathrm{l}$ of $10 \mathrm{mg} \mathrm{ml}^{-1}$ Protease $\mathrm{K}$ solution (Sigma, Type XI, fungal) in $12 \times 75 \mathrm{~mm}$ borosilicate test tubes. All solutions were kept at $0{ }^{\circ} \mathrm{C}$ in an ice bath during these procedures to prevent autolytic degradation of nucleic acids.

Samples were incubated at $37^{\circ} \mathrm{C}$ for $1 \mathrm{~h}$, allowed to cool for $5 \mathrm{~min}$, then $500 \mathrm{ml}$ of buffer $(80 \mathrm{mM}$ TRIS, $3.2 \mathrm{mM} \mathrm{CaCl}_{2}, 4.0 \mathrm{mM} \mathrm{MgCl}_{2}, \mathrm{pH}=7.5$ ) were added to each tube. Initial fluorescence values were measured with a Shimadzu Model RF-540* spectrofluorophotometer at excitation and emission wavelengths of $365 \mathrm{~nm}$ and $590 \mathrm{~nm}$, respectively.

Samples were then treated with $5 \mu \mathrm{l}$ of $5 \mathrm{mg} \mathrm{ml}^{-1}$ RNase solution (Sigma, Type I-A, bovine pancreas), vortexed, and incubated for $40 \mathrm{~min}$ at $37^{\circ} \mathrm{C}$. The tubes were allowed to cool for $5 \mathrm{~min}$ before sample fluorescence was remeasured. Five $\mu \mathrm{l}$ of $1 \mathrm{mg} \mathrm{ml}^{-1}$ DNase (Sigma, Type II, bovine pancreas) were added to each tube, samples were incubated another $30 \mathrm{~min}$ at $37^{\circ} \mathrm{C}$, and final sample fluorescence values were measured.

Fluorescence due to RNA was determined by subtracting middle fluorescence values from initial

\footnotetext{
- Reference to trade names does not imply endorsement by the United States Government
} 
readings after correcting for reagent blanks. Fluorescence due to DNA was calculated after correcting for a $4 \%$ contamination of the RNA standard by DNA (Bentle et al, 1981). Nucleic acid concentrations were determined from standard regression curves for RNA (Sigma, Type III, Baker's yeast) and DNA (Sigma, Type I, calf thymus) run with each assay. Concentrations of the standards were determined spectrophotometrically following perchloric acid hydrolysis as outlined by Bentle et al. (1981).

Microzooplankton were identified under a dissecting microscope. We determined from initial examination of the sample whether or not it should be subdivided before analysis. Samples were examined in entirety when they contained fewer than about 300 organisms; otherwise, we used subsamples of not less than $25 \%$ of the original sample. Most of the analysis focussed on copepod nauplii. Total body length, excluding appendages, and minimum body width were measured on all nauplii that were counted. In addition, total body length and prosome length were measured for comparison on 90 individuals. All measurements were made and data stored with a computer imaging system that provided routine replication of measurements to within $4 \mu \mathrm{m}$ (Incze et al. 1990).

\section{RESULTS}

Stomach contents of 342 pollock larvae were examined from samples obtained during Cruises 2MF89 and 3MF89 (Table 1). Dietary composition by cruise and location was determined for larvae 5.0 to $7.0 \mathrm{~mm}$ in length from the later cruise (3MF89) but was restricted to larvae 5.0 to $6.0 \mathrm{~mm}$ in length from the earlier cruise (2MF89) due to insufficient numbers of fish in larger size classes.
Copepod nauplii and eggs comprised the bulk of the diet, averaging 93.0 and $5.5 \%$ of total prey, respectively, for all collections. Prosome lengths of prey nauplii ranged from 125 to $400 \mu \mathrm{m}$ with a mean of $210 \mu \mathrm{m}$. Few prey remains were unidentified in larvae from the earlier cruise (2MF89) and percentages of unidentified prey increased only slightly in diets of the larger larvae sampled in the later cruise (3MF89).

Microzooplankton concentrations were analyzed from samples taken from 0 to $40 \mathrm{~m}$, the depth strata where most pollock larvae occur in Shelikof Strait (Kendall et al. 1987). Average microzooplankton densities from 0 to $40 \mathrm{~m}$ in depth for stations inside the patch and outside of the patch during cruise 2MF89 were 23.1 and 12.5 nauplii $1^{-1}$, respectively (Fig. 3 ). During Cruise 3MF89, average concentrations for inside the patch and outside of the patch stations were 26.0 and 20.9 nauplii $1^{-1}$. Microzooplankton consisted almost entirely of copepod nauplii and eggs. The prosome lengths of nauplii ranged from 100 to $300 \mu \mathrm{m}$ with a mean length of ca $200 \mu \mathrm{m}$.

The mean number of prey per larva ranged from 2.25 to 9.32 (Table 1) and increased as a function of larval size for all collections (Fig. 4). Differences in the number of prey larva ${ }^{-1}$ between cruise and location and their interaction were compared using a nested analysis of covariance (ANCOVA) with larval standard length as the covariate (Table 2). Initial comparisons showed no significant interaction effects between cruise and location with larval standard length and those terms were omitted to provide a more robust model. Pollock larvae from Cruise 2MF89 stations outside of the patch contained significantly lower numbers of prey than larvae from Cruise 2MF89 stations inside the patch or larvae of similar size from either location in Cruise 3MF89. Slight differences between times of collection during Cruise 2MF89 had

Table 1. Theragra chalcogramma. Dietary composition, incidence of feeding, and mean number of prey larva ${ }^{-1}$ for pollock larvae collected in and out of larval patch stations during late April-early May 1989 (Cruise 2MF89) and mid-May (Cruise 3MF89)

\begin{tabular}{|c|c|c|c|c|}
\hline & \multicolumn{2}{|c|}{ 2MF89 } & \multicolumn{2}{|c|}{ 3MF89 } \\
\hline & In patch & Out of patch & In patch & Out of patch \\
\hline Time of day (h) & $15: 00-22: 30$ & $11: 30-15: 30$ & $10: 00-22: 00$ & $08: 30-22: 00$ \\
\hline Standard length (mm) & $5.0-6.0$ & $5.0-6.0$ & $5.0-7.0$ & $5.0-7.0$ \\
\hline No. larvae & 60 & 60 & 93 & 129 \\
\hline$\%$ Fed larvae & 98.3 & 73.3 & 100.0 & 100.0 \\
\hline Total prey items & 301 & 141 & 928 & 1149 \\
\hline Prey larva $^{-1}$ (SD) & $5.27(2.44)$ & $2.25(2.32)$ & $9.32(4.64)$ & $8.73(4.99)$ \\
\hline \multicolumn{5}{|l|}{ Prey items ( $\%$ of total) } \\
\hline Copepod nauplii & 88.7 & 96.4 & 90.9 & 95.6 \\
\hline Copepod eggs & 10.6 & 2.9 & 6.1 & 2.4 \\
\hline Euphausiid nauplii & 0 & 0 & 1.3 & 0 \\
\hline Unidentified crustaceans & 0.7 & 0.7 & 0.4 & 0.1 \\
\hline Unidentified eggs & 0 & 0 & 0.4 & 0.3 \\
\hline Unidentified other & 0 & 0 & 0.8 & 1.6 \\
\hline
\end{tabular}




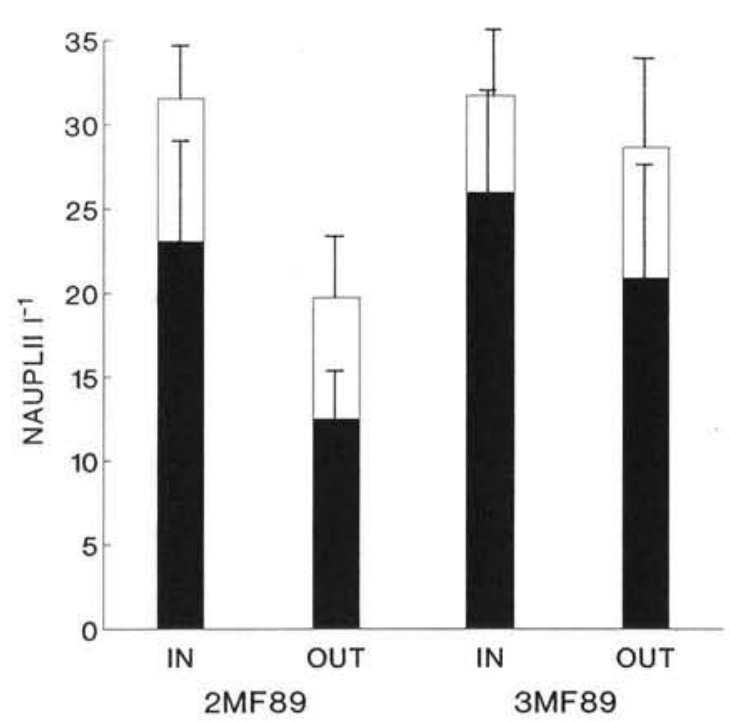

Fig. 3. Theragra chalcogramma. Mean integrated (black bar) and maximum (open bar) naupliar concentrations from 0 to $40 \mathrm{~m}$ for stations inside (IN) and outside (OUT) of the larval patch during Cruise 2MF89 (27 April to 2 May 1989) and Cruise 3MF89 (9 to 16 May 1989). Error bars represent one standard deviation of the mean

no significant effect upon the number of prey ingested by pollock larvae when incorporated in the ANCOVA model $(F=3.27, \mathrm{p}>0.05)$. The mean number of prey larva $^{-1}$ from Cruise 2MF89 inside the patch, while greater than 2MF89 outside the patch samples, was significantly lower than values from either location during Cruise 3MF89.

Daily food rations for larvae from both cruises ranged from 7.2 to 27.9 prey larva ${ }^{-1} \mathrm{~d}^{-1}$ (Table 3 ). Weight-specific rations ranged from 1.8 to $7.2 \%$ of body dry weight $\mathrm{d}^{-1}$ and 1.6 to $6.5 \%$ of body carbon $\mathrm{d}^{-1}$. Pollock larvae from out of patch stations during Cruise 2MF89 had the lowest rations while larvae from stations in the patch, and from both loca-

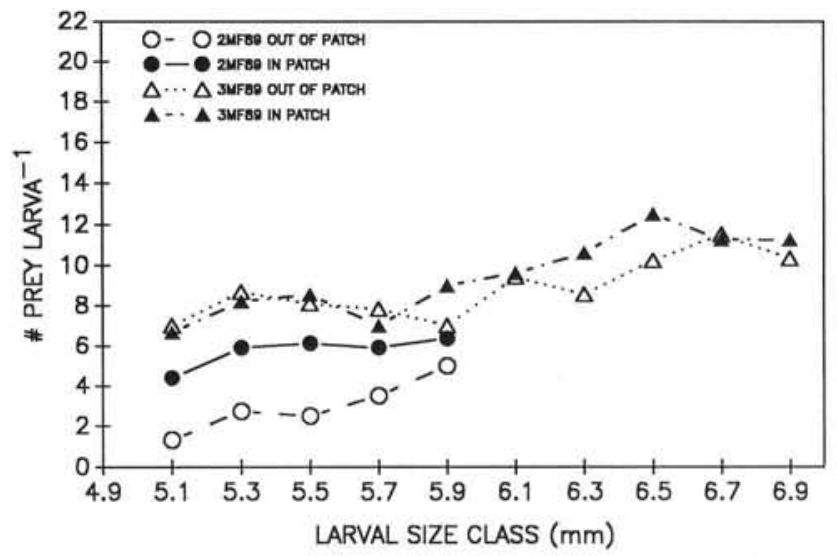

Fig. 4. Theragra chalcogramma. Mean number of prey larva ${ }^{-1}$ in pollock larvae collected during Cruises 2MF89 (27 April to 2 May 1989) and 3MF89 (9 to 16 May 1989)

tions during Cruise 3MF89, had significantly higher rations.

RNA/DNA values exhibited similar trends to feeding intensity by cruise and location (Table 4 ). The ratios increased with larval standard length in all areas during both cruises. Pollock larvae sampled from stations outside of the patch during Cruise 2MF89 had the lowest mean RNA/DNA value (1.56) from all locations. RNA/DNA values from larvae inside the patch from Cruise 2MF89 were significantly higher than those for larvae sampled outside of the patch stations during the same cruise (Fig. 5) and were lower than RNA/DNA values from either location during Cruise 3MF89 (Fig. 6). The highest mean RNA/DNA recorded in this study (2.45) was for larvae from inside the patch during Cruise 3MF89, but this value was not significantly higher than from mean RNA/DNA from samples taken outside of the patch during the same cruise (ANCOVA, $\mathrm{p}>0.1$ ).

Table 2. Theragra chalcogramma. Summary statistics and analysis of covariance (ANCOVA) for comparisons of the number of prey larva ${ }^{-1}$ between stations in and out of the larval patch sampled during late April-early May 1989 (Cruise 2MF89) and midMay 1989 (Cruise 3MF89)

\begin{tabular}{|c|c|c|c|c|c|c|c|}
\hline Source & Level & $\mathrm{n}$ & $\begin{array}{l}\text { Mean no. prey } \\
\text { larva }^{-1}(\mathrm{SD})\end{array}$ & df & $\begin{array}{l}\text { Mean } \\
\text { squares }\end{array}$ & $F$-ratio & $\mathrm{p}$ \\
\hline Cruise & $\begin{array}{l}\text { 2MF89 } \\
\text { 3MF89 }\end{array}$ & $\begin{array}{l}120 \\
121\end{array}$ & $\begin{array}{l}3.75(2.83) \\
7.87(3.87)\end{array}$ & 1 & 771.77 & 76.94 & 0.000 \\
\hline Location within 2MF89 & $\begin{array}{l}\text { In patch } \\
\text { Out of patch }\end{array}$ & $\begin{array}{l}60 \\
60\end{array}$ & $\begin{array}{l}5.27(2.44) \\
2.25(2.32)\end{array}$ & 1 & 194.04 & 19.34 & 0.000 \\
\hline Location within 3MF89 & $\begin{array}{l}\text { In patch } \\
\text { Out of patch }\end{array}$ & $\begin{array}{l}45 \\
76\end{array}$ & $\begin{array}{l}7.91(4.08) \\
7.84(3.78)\end{array}$ & 1 & 0.57 & 0.06 & 0.811 \\
\hline Standard length $(\mathrm{mm})$ & & & & 1 & 86.11 & 8.58 & 0.004 \\
\hline Error & & & & 236 & 10.03 & & \\
\hline
\end{tabular}


Table 3. Theragra chalcogramma. Daily rations $\left(D\right.$, in terms of prey larva $\left.{ }^{-1} \mathrm{~d}^{-1}\right)$ and daily weight-specific rations of dry weight and carbon as percentages of body weight for $5.5 \mathrm{~mm}$ pollock larvae from in and out of larval patch stations during Cruises 2MF89 and 3MF89. Rations are calculated based on a $5.0 \mathrm{~h}$ digestion time

\begin{tabular}{|c|c|c|c|c|c|c|}
\hline Location & $\begin{array}{l}\text { Mean no. } \\
\text { prey larva }^{-1}\end{array}$ & $\begin{array}{l}\text { Daily ration }(D) \\
\left(\text { prey larva }^{-1} \mathrm{~d}^{-1}\right)\end{array}$ & $\begin{array}{c}\text { Prey dry } \\
\text { weight } \\
(\mu g)\end{array}$ & $\begin{array}{l}\text { Weight- } \\
\text { specific } \\
\text { ration }^{\circ}\end{array}$ & $\begin{array}{c}\text { Prey } \\
\text { carbon } \\
(\mu g)\end{array}$ & $\begin{array}{c}\text { Carbon- } \\
\text { specific } \\
\text { ration }^{b}\end{array}$ \\
\hline 2MF89 in patch & 5.3 & 16.9 & 0.37 & 4.3 & 0.15 & 3.9 \\
\hline 2MF89 out of patch & 2.5 & 7.2 & 0.35 & 1.8 & 0.14 & 1.6 \\
\hline 3MF89 in patch & 8.7 & 27.9 & 0.37 & 7.2 & 0.15 & 6.5 \\
\hline $3 \mathrm{MF} 89$ out of patch & 8.4 & 26.8 & 0.31 & 5.8 & 0.14 & 5.8 \\
\hline
\end{tabular}

CTD profiles conducted at grid stations on the same days as RNA/DNA sampling during both cruises did not show obvious stratification in temperature or $\sigma_{t}$ distribution between stations inside or outside of the larval patch (J. Schumacher, Pacific Marine Environmental Laboratory, Seattle, pers. comm.). Water temperatures from 0 to $40 \mathrm{~m}$ ranged from 2.8 to $3.7^{\circ} \mathrm{C}$ with a mean of $3.4^{\circ} \mathrm{C}$ during Cruise 2MF89 and averaged ca $1^{\circ} \mathrm{C}$ higher during Cruise 3MF89.

\section{DISCUSSION}

Our results suggest that the timing and distribution of seasonal copepod production may have a significant effect upon the feeding and growth of pollock larvae. Gut analyses from this study confirm other reports (Kamba 1977, Clarke 1978, 1984, Nishiyama \& Hirano 1983, 1985, Dagg et al. 1984, Kendall et al. 1987) that copepod nauplii are the most important food item during the initial stages of feeding. Microzooplankton densities, excluding those from out of patch stations during late April-early May, were similar to those given by Incze et al. (1990) for the same area during early May 1987 and were slightly higher than those reported for the southeastern Bering Sea by Dagg et al. (1984) during late May 1981.

The gut contents of pollock larvae exhibited a clear relationship with food concentrations. Average integrated prey densities at all stations during mid-May were nearly double those found at stations outside the patch during the earlier cruise, but were not very different from those found inside the patch during Cruise 2MF89. In general, gut fullness was positively related to food concentration, with the highest mean number of prey larva ${ }^{-1}$ in this study occurring in areas of highest microzooplankton abundance.

Observed RNA/DNA values and reduced feeding intensity in areas of lower naupliar concentration suggest that some degree of food-limited growth occurred during late April-early May. First-feeding larvae hatched from eggs reared in the laboratory at $6{ }^{\circ} \mathrm{C}$ have RNA/DNA values ranging from 1.6 to 1.8 , which rapidly decline if feeding is not initiated by the time yolk absorption is completed; pollock larvae which have been starved for $7 \mathrm{~d}$ have RNA/DNA values of ca 1.0 and will not recover even if fed (Canino \& Bailey unpubl.). Mean RNA/DNA values for larvae

Table 4. Theragra chalcogramma. Summary statistics and analysis of covariance (ANCOVA) table for comparisons of mean RNA/DNA ratios of pollock larvae from stations inside and outside of the larval patch sampled during late April-early May 1989 (Cruise 2MF89) and mid-May 1989 (Cruise 3MF89)

\begin{tabular}{|c|c|c|c|c|c|c|c|}
\hline Source & Level & $\mathrm{n}$ & $\begin{array}{l}\text { RNA/DNA } \\
\text { (SD) }\end{array}$ & df & $\begin{array}{l}\text { Mean } \\
\text { squares }\end{array}$ & F-ratio & $\mathrm{p}$ \\
\hline Cruise & $\begin{array}{l}\text { 2MF89 } \\
\text { 3MF89 }\end{array}$ & $\begin{array}{r}39 \\
103\end{array}$ & $\begin{array}{l}1.76(0.34) \\
2.41(0.41)\end{array}$ & 1 & 10.81 & 97.30 & 0.000 \\
\hline Location within 2 MF89 & $\begin{array}{l}\text { In patch } \\
\text { Out of patch }\end{array}$ & $\begin{array}{l}19 \\
20\end{array}$ & $\begin{array}{l}1.96(0.32) \\
1.56(0.23)\end{array}$ & 1 & 1.43 & 12.84 & 0.000 \\
\hline Location within 3MF89 & $\begin{array}{l}\text { In patch } \\
\text { Out of patch }\end{array}$ & $\begin{array}{l}55 \\
48\end{array}$ & $\begin{array}{l}2.45(0.46) \\
2.38(0.34)\end{array}$ & 1 & 0.03 & 0.30 & 0.596 \\
\hline Standard length (mm) & & & & 1 & 4.47 & 40.18 & 0.000 \\
\hline Error & & & & 137 & & & \\
\hline
\end{tabular}




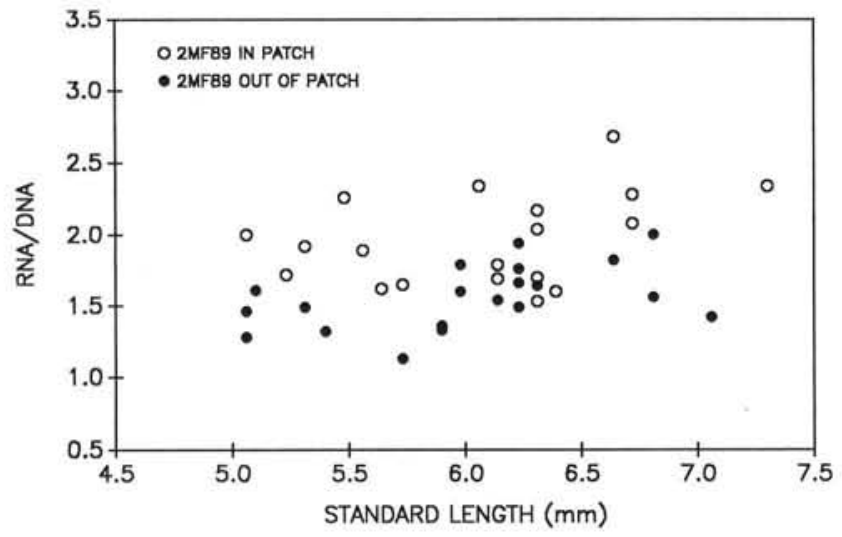

Fig. 5. Theragra chalcogramma. RNA/DNA pollock larvae collected inside and outside of patch stations during Cruise 2MF89 (27 April to 2 May 1989)

outside of the patch during late April-early May are approaching these starvation levels. Incipient growth is reflected in larval RNA/DNA ratios from mid-May, when food densities were higher. The overall range of RNA/DNA values determined for pollock in this study is similar to those reported for field-captured larvae of striped bass (Martin et al. 1985, Setzler-Hamilton et al. 1987), Pacific herring (Robinson \& Ware 1988), and plaice (Hovenkamp 1990), although somewhat less than those for older cod and haddock larvae given by Buckley \& Lough (1987).

While a number of laboratory studies (Buckley 1979 , 1981, 1984, Buckley et al. 1984) have established relationships between larval fish growth rate, RNA/DNA, and temperature at different food levels, there are relatively few data available for wild larvae. Buckley (1984) demonstrated that daily protein growth rates for 8 species of marine fish larvae could be estimated from RNA/DNA values and temperatures. Robinson \& Ware

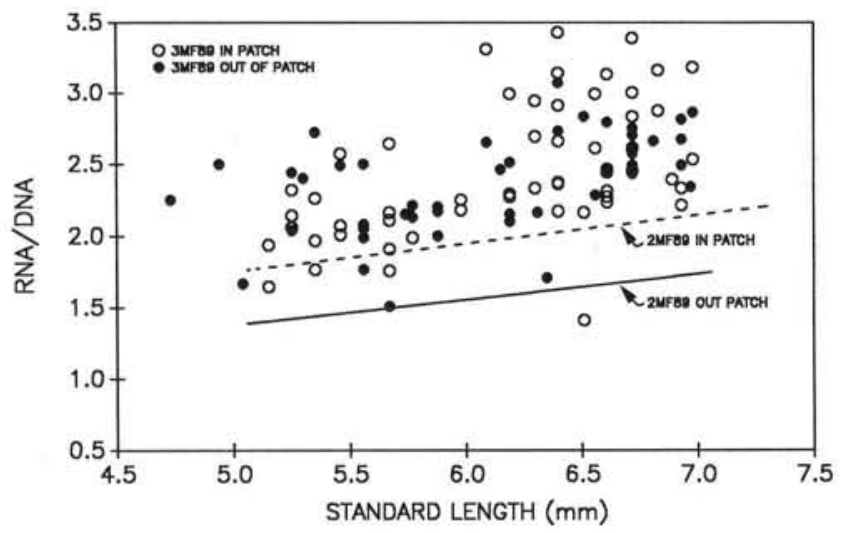

Fig. 6. Theragra chalcogramma. RNA/DNA ratios of pollock larvae collected inside and outside of patch stations during Cruise 3MF89 (9 to 16 May 1989). Regression lines are drawn for 2MF89 data for comparison with Fig. 5
(1988) subsequently modified Buckley's equation to estimate the 'critical ratio' of RNA/DNA, $R_{\text {crit, where }}$ net protein synthesis equals zero, and applied it to in situ RNA/DNA values from a cohort of Pacific herring Clupea harengus pallasi larvae. The highest percentages of larvae with RNA/DNA values below $R_{\text {crit }}$ (i.e. negative protein growth) occurred during the time of yolk-sac exhaustion and the initial stages of exogenous feeding.

Hovenkamp (1990) reported significant differences in RNA/DNA values and recent somatic growth between 2 groups of plaice Pleuronectes platessa larvae sampled $11 \mathrm{~d}$ apart. Most (88\%) of the larvae from the earlier group had RNA/DNA values less than $R_{\text {crit }}$ while all larvae from the later sampling date had ratios above $R_{\text {crit }}$ and positive daily protein growth rates.

Caution may be necessary equating values from different techniques without extensive intercalibration between methods. Results can vary significantly, even within a given method, depending upon the choice of standards, buffers, and extraction procedures. For example, critical RNA/DNA values, when applied to our data (Eq. 2 in Robinson \& Ware 1988), indicate that all larvae sampled during Cruise 2MF89 were below the critical ratio $\left(R_{\text {crit }}=3.14\right)$, and only 8 to $11 \%$ of larvae sampled during Cruise 3MF89 had positive growth rates $\left(R_{\text {crit }}=2.95\right)$.

The calculations suggest that ambient food concentrations, while high enough to initiate feeding, were not adequate to sustain growth of larval pollock. One additional problem in the interpretation of these results is that quantitative knowledge of RNA/DNA values and growth as functions of ingestion by larval fish is lacking; prey concentrations in laboratory cultures typically exceed realistic field densities by at least an order of magnitude, making comparisons between the two somewhat tenuous.

Weight-specific rations calculated from laboratory measurements of larval respiration (Incze et al. 1984) or larval ingestion (Yamashita \& Bailey 1989) range from 21.5 to $29 \%$ of body dry weight $\mathrm{d}^{-1}$. Incze et al. (1984) estimated that post yolk-sac pollock larvae would require a carbon-specific ration of ca $15.0 \% \mathrm{~d}^{-1}$ to meet requirements for metabolism and growth. Assuming that the mean carbon weight of a prey nauplius is $0.14 \mu \mathrm{g} \mathrm{C}$, a $5.5 \mathrm{~mm}$ larvae would require about 69 nauplii $\mathrm{d}^{-1}$ for maintenance and growth. This estimate is close to the ration of 75 nauplii $\mathrm{d}^{-1}$ for pollock larvae in the Bering Sea determined by Clarke (1984), but much lower than the estimated ration of 161 nauplii $\mathrm{d}^{-1}$ for Atlantic cod Gadus morhua larvae in the Irish Sea (Thompson \& Harrop 1991).

Our estimates of daily rations for pollock larvae during mid-May, ca 27 prey larva ${ }^{-1} \mathrm{~d}^{-1}$, are most comparable to the ration of 18.3 prey larva ${ }^{-1} \mathrm{~d}^{-1}$ deter- 
mined from gut contents for first-feeding pollock larvae in the southeastern Bering Sea (Dagg et al. 1984). It is of interest to note that food rations for larval pollock calculated from gut contents are consistently lower than estimates derived from measuring bioenergetic rates in the laboratory; either method may be subject to several sources of error. Calculations of daily food consumption in this study did not include the small contributions of copepod eggs and unidentified prey items to the diet or losses due to evacuation during capture and, therefore, may underestimate rations to some extent. The assumption of constant rates of ingestion and gut passage for pollock larvae is probably simplistic. Elliott \& Persson (1978) noted that gut clearing rates for many fish are exponential and that application of Bajkov's (1935) equation to gut contents would underestimate food consumption in these cases. Yamashita \& Bailey (1989) described exponential rates of ingestion and gastric evacuation of pollock larvae feeding on rotifers that were dependent upon the size of the larvae and the amount of ingested food. However, exponential rates of gut evacuation based upon comparable numbers or weight of naupliar prey are not available, and may differ considerably from those obtained with soft-bodied rotifers.

The prey densities necessary to support growth of pollock larvae may be approximated from estimated food rations and assumptions about capture success. Although there is evidence that gadoid larvae may feed more effectively than other marine fish larvae at low food concentrations (Ellertsen et al. 1981, Paul 1983, Clarke 1984), first-feeding pollock may not have high capture efficiencies. Tilseth (1984) found that Gadus morhua larvae searched a mean volume of $4.57 \mathrm{l}^{-1} \mathrm{~d}^{-1}$ with a mean capture success of $15.2 \%$ during the first $4 \mathrm{~d}$ of feeding. Assuming that pollock larvae have a similar search volume, capture efficiency, and $16 \mathrm{~h}$ of feeding during May, average food densities of 190 prey $1^{-1}$ and 139 prey $1^{-1}$ would be required to provide specific rations of $21.5 \%$ of body dry weight $\mathrm{d}^{-1}$ and $15.0 \%$ of body carbon $\mathrm{d}^{-1}$, respectively. These calculated requirements greatly exceed average naupliar abundance measured in Shelikof Strait and the southeastern Bering Sea. In contrast, average prey densities of 39 to 58 prey $1^{-1}$ would be sufficient to provide daily rations of 18 to 28 prey larva ${ }^{-1} \mathrm{~d}^{-1}$ estimated from gut contents in field studies (Dagg et al. 1984, this study). These estimates are still slightly higher than typical microzooplankton densities in the area (Incze et al. 1990), and may be influenced by bias in ration estimates. It is also recognized that integrated microplankton abundance reported in this study do not accurately represent ambient prey availability to the larvae; patchiness of food distributions may have a greater influence than average abundance in determining whether adequate rations for growth are attained.

Larval mortality rates for most pelagic fishes are commonly high. Meso-scale spatial/temporal matches or mismatches between first-feeding larvae and their prey can have significant effects upon rates of feeding, growth, and subsequent survival. Even relatively small differences in larval mortality rates may result in considerable variation in juvenile recruitment (Houde 1987).

Microzooplankton concentrations, larval gut contents, and RNA/DNA values indicate that better conditions for the feeding and growth of larvae occurred during mid-May; eggs spawned ca 2 wk earlier in the season may have reached first-feeding stages when microzooplankton densities outside of the larval patch were insufficient to support growth. These results indicate that starvation may be a significant source of mortality during certain periods, but perhaps more importantly, gut contents and RNA/DNA values for larvae in areas of low food concentrations infer suboptimal growth and extended duration at size which may contribute to predation mortality in the early larval stages.

Acknowledgements. This research was conducted as part of the Fisheries Oceanography Coordinated Investigations (NOAA, Seattle): FOCI contribution no. 0135 and Bigelow Laboratory contribution no. 91025. We thank Dr Sandor Kaupp for information on fluorometric analyses of nucleic acids, Dr J. Schumacher for providing CTD data, Terri Ainaire for processing the microzooplankton samples, and S. Spring for assistance with gut content analyses. The authors also thank Drs A. Kendall, J. Napp, G. Stauffer, L. Fritz, and several anonymous reviewers for their helpful comments on drafts of this manuscript.

\section{LITERATURE CITED}

Bajkov, A. D. (1935). How to estimate the daily food consumption of fish under natural conditions. Trans. Am. Fish. Soc. 65: $288-289$

Bentle, L. A., Dutta, S., Metcoff, J. (1981). The sequential enzymatic determination of DNA and RNA. Analyt. Biochem. 116: 5-16

Buckley, L. J. (1979). Relationships between RNA-DNA ratio, prey density, and growth rate in Atlantic cod (Gadus morhua) larvae. J. Fish. Res. Bd Can. 36: 1497-1502

Buckley, L. J. (1980). Changes in ribonucleic acid, deoxyribonucleic acid, and protein content during ontogenesis in winter flounder (Pseudopleuronectes americanus) and effect of starvation. Fish. Bull. U.S. 77: 703-708

Buckley, L. J. (1981). Biochemical changes during ontogenesis of cod (Gadus morhua L.) and winter flounder (Pseudopleuronectes americanus) larvae. Rapp. P.-v. Réun. Cons. int. Explor. Mer 178: 547-552

Buckley, L. J. (1984). RNA-DNA ratio: an index of larval fish growth in the sea. Mar. Biol. 80: 291-298

Buckley, L. J., Lough, R. G. (1987). Recent growth, biochemical composition, and prey field of larval haddock (Melano- 
grammus aeglefinus) and Atlantic cod (Gadus morhua) on Georges Bank. Can. J. Fish. Aquat. Sci. 44: 14-25

Buckley, L. J., Turner, S. I., Halavik, T. A., Smigielski, A. S. Drew, S. M., Laurence, G. C. (1984). Effects of temperature and food availability on growth, survival, and RNADNA ratio of larval sand lance (Ammodytes americanus). Mar. Ecol. Prog. Ser. 15: 91-97

Bulow, F. J. (1987). RNA-DNA ratios as indicators of growth in fish: a review. In: Summerfelt, R. C., Hall, G. E. (eds.) The age and growth of Fish. Iowa State University Press, Ames, p. 45-64

Clarke, M. E. (1978). Some aspects of the feeding biology of larval walleye pollock, Theragra chalcogramma (Pallas), in the southeastern Bering Sea. M.S. thesis, Univ. of Alaska, Fairbanks

Clarke, M. E. (1984). Feeding behavior of larval walleye pollock, Theragra chalcogramma (Pallas) and food availability to larval pollock in the southeastern Bering Sea. $\mathrm{Ph} . \mathrm{D}$. thesis, Univ. of California, San Diego

Clemmensen, C. M. (1987). Laboratory studies on RNA/DNA ratios of starved and fed herring (Clupea harengus) and turbot (Scopthalmus maximus). J. Cons. int. Explor. Mer 43: $122-128$

Clemmensen, C. M. (1988). A RNA and DNA fluorescence technique to evaluate the nutritional condition of individual fish larvae. Meeresforsch. 32: 134-143

Dagg, M. J., Clarke, M. E., Nishiyama, T., Smith, S. L. (1984). Production and standing stock of copepod nauplii, food items for larvae of the walleye pollock Theragra chalcogramma in the southeastern Bering Sea. Mar. Ecol. Prog. Ser. 19: 7-16

Davis, C. S. (1984). Predatory control of copepod seasonal cycles on Georges Bank. Mar. Biol. 82: 31-40

Ellertsen, B., Solemdal, P., Sundby, S., Tilseth, S., Westgard, T., Øiestad, V. (1981). Feeding and vertical distribution of cod larvae in relation to availability of prey organisms. Rapp. P.-v. Réun. Cons. int. explor. Mer 178: 317-319

Elliot, J. M., Persson, L. (1978). The estimation of daily rates of food consumption for fish. J. Anim. Ecol. 47: 977-991

Harris, R. K. (1985). Body composition (carbon, nitrogen and calories) and energetics of immature walleye pollock, Theragra chalcogramma (Pallas) in the southeast Bering Sea. Ph.D. thesis, Univ. of Alaska, Fairbanks

Houde, E. D. (1987). Fish early life dynamics and recruitment variability. Am. Fish. Soc. Symp. 2: 17-29

Hovenkamp, F. (1990). Growth differences in larval plaice Pleuronectes platessa in the southern bight of the North Sea as indicated by otolith increments and RNA/DNA ratios. Mar. Ecol. Prog. Ser. 58: 205-215

Incze, L. S., Clarke, M. E., Goering, J. J., Nishiyama, T., Paul, A. J. (1984). Eggs and larvae of walleye pollock and relationships to the planktonic environment. In: Ito, D. H. (ed.) Proceedings of the workshop on walleye pollock and its ecosystem in the eastern Bering Sea, NOAA Tech Memo. NMFS F/NWC-62, p. 109-159

Incze, L. S., Ortner, P. B., Schumacher, J. D. (1990). Microzooplankton, vertical mixing and advection in a larval fish patch. J. Plankton Res. 12: 365-379

Kamba, M. (1977). Feeding habits and vertical distribution of walleye pollock, Theragra chalcogramma (Pallas), in early life stages in Uchiura Bay, Hokkaido, Res. Inst. N. Pac. Fish., Hokkaido Univ., Spec. Vol., p. 175-197

Kendall, A. W., Jr, Clarke, M. E., Yoklavich, M. M., Boehlert, G. W. (1987). Distribution, feeding, and growth of larval walleye pollock, Theragra chalcogramma, from Shelikof Strait, Gulf of Alaska. Fish. Bull. U.S. 85: 499-521

Kendall, A. W., Jr, Picquelle, S. J. (1990). Egg and larval distributions of walleye pollock Theragra chalcogramma in Shelik of Strait, Gulf of Alaska. Fish. Bull. U.S. 88: 133-154

Kim, S., Kendall, A. W., Jr (1989). Distribution and transport of larval walleye (Theragra chalcogramma) in Shelikof Strait, Gulf of Alaska, in relation to water movement. Rapp. P.-v. Réun. Cons. int. Explor. Mer 191: 127-136

Landry, M. R., Lorenzen, C. J. (1989). Abundance, distribution, and grazing impact of zooplankton on the Washington shelf. In: Landry, M. R., Hickey, B. M. (eds.) Coastal oceanography of Washington and Oregon. Elsevier Amsterdam, p. 175-210

Martin, F. D., Wright, D. A., Means, J. C., Setzler-Hamilton, E. M. (1985). Importance of food supply to nutritional state of larval striped bass in the Potomac River Estuary. Trans. Am. Fish. Soc. 114: 137-145

Nakatani, T. (1988). Studies on the early life history of walleye pollock Theragra chalcogramma in Funka Bay and vicinity, Hokkaido. Mem. Fac. Fish. Hokkaido Univ. 35: 1-45

Nishiyama, T., Hirano, K. (1983). Estimation of zooplankton weight in the gut of larval walleye pollock (Theragra chalcogramma). Bull. Plankton Soc. Japan 30: 159-170

Nishiyama, T., Hirano, K. (1985). Prey size and weight relations in larval walleye pollock (Theragra chalcogramma). Bull. Plankton Soc. Japan 32: 45-59

Paul, A. J. (1983). Light, temperature, nauplii concentrations, and prey capture by first feeding pollock larvae Theragra chalcogramma. Mar. Ecol. Prog. Ser. 13: 175-179

Posgay, J. A., Marak, R. R. (1980). The MARMAP bongo zooplankton samplers. J. Northwest Atl. Fish. Sci. 1: 91-99

Richard, P., Bergeron, J-P., Boulhic, M., Galois, R., Person-Le Ruyet, J. (1991). Effect of starvation on RNA, DNA and protein content of laboratory-reared larvae and juveniles of Solea solea. Mar. Ecol. Prog. Ser. 72: 69-77

Robinson, S. M. C., Ware, D. M. (1988). Ontogenetic development of growth rates in larval Pacific herring, Clupea harengus pallasi, measured with RNA-DNA ratios in the Strait of Georgia, British Columbia. Can. J. Fish. Aquat. Sci. 45: 1422-1429

Setzler-Hamilton, E. M., Wright, D. A., Martin, F. D., Millsaps, C. V., Whitlow, S. I. (1987). Analysis of nutritional condition and its use in predicting striped bass recruitment: field studies. Am. Fish. Soc. Symp. 2: 115-128

Siefert, D. L. W., Incze, L. S. (1991). Zooplankton of Shelikof Strait, Alaska, April and May 1989: data from Fisheries Oceanography Coordinated Investigations (FOCI) cruises. NWAFC Processed Rep. 91-16. Alaska Fish. Sci. Cent., Seattle

Thompson, A. B., Harrop, R. T. (1991). Feeding dynamics of fish larvae on Copepoda in the western Irish Sea, with particular reference to cod Gadus morhua. Mar. Ecol. Prog. Ser. 68: 213-223

Tilseth, S. (1984). The distribution of cod larvae and prey organisms in the Lofoten area related to critical prey concentrations. In: Godø, O. R., Tilseth, S. (eds.) Reproduction and recruitment of arctic cod. Institute of Marine Research, Bergen, p. 41-71

Wright, D. A., Martin, F. D. (1985). The effect of starvation on RNA:DNA ratios and growth of larval striped bass, Morone saxatalis. J. Fish. Biol. 27: 479-485

Yamashita, Y., Bailey, K. M. (1989). A laboratory study of the bioenergetics of larval walleye pollock, Theragra chalcogramma. Fish. Bull. U.S. 87: 525-536

Yamashita, Y., Bailey, K. M. (1990). Electron transport system (ETS) activity as a possible index of respiration for larval walleye pollock Theragra chalcogramma. Nippon Suisan Gakkaishi 56: 1059-1062 